\title{
IMPLEMENTATION OF ICT AND DIGITAL TECHNOLOGIES Within Higher EDUCATION
}

\author{
JAKOVIC, B.
}

Abstract: We are facing many challenges due to COVID-19 crisis in many sectors, higher education is no exception. Although higher education systems are mostly traditionally oriented offering traditional study programmes using traditional study methods and techniques, with implementation of ICT and digital technologies, they can effectively answer many of the challenges related to COVID-19 crisis. Aim of this paper is to show how ICT and digital technologies could help in higher education system so that the educational process could continue despite all restrictions and challenges of COVID-19 crisis. Main focus will be on different aspects of how to use ICT and digital technologies within higher education systems: within the learning process, application of new students for study programmes, communication with teachers, communication and services with the student office, communication and services with other offices related to student activities and other activities related to student life.

Key words: ICT, Digital Technologies, COVID-19 Crisis, Higher Education
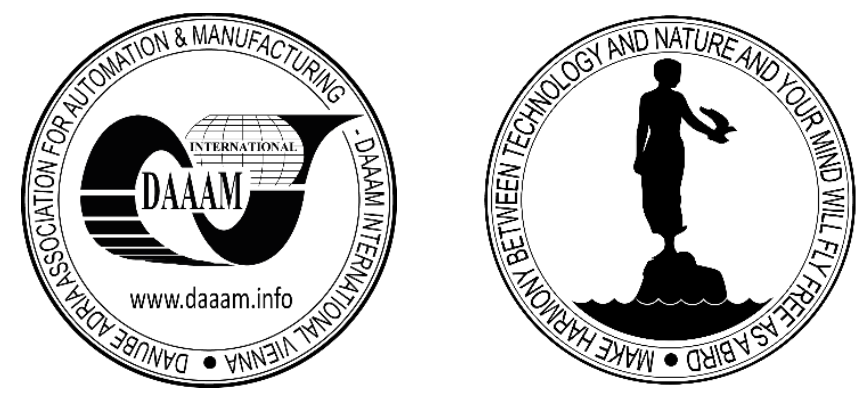

Authors' data: Univ.Prof. Jakovic, B[ozidar]*; *University of Zagreb - Croatia, Faculty of Economics and Business, Square J.F.Kennedy 6, 10000, Zagreb, Croatia, bjakovic@efzg.hr

This Publication has to be referred as: Jakovic, B[ozidar] (2021). Implementation of ICT and Digital Technologies Within Higher Education, Chapter 02 in DAAAM International Scientific Book 2021, pp.021-028, B. Katalinic (Ed.), Published by DAAAM International, ISBN 978-3-902734-31-0, ISSN 1726-9687, Vienna, Austria DOI: $10.2507 /$ daaam.scibook.2021.02 
Jakovic, B.: Implementation of ICT and Digital Technologies Within Higher Educa...

\section{Introduction}

In the last two years we are facing many challenges due to COVID-19 crisis. Health consequences, diminishing stock market values, general recession and increasing unemployment are having devastating effects on the world's economies. The closing of borders has also affected the structure (production, supply chains, logistics and cross-border employment) of most multinational companies. The global economy, with its free trade areas and collaboration, has been breaking up and has seemingly been followed by the building of more nationalistic economies. This makes it necessary for us to consider new ways to manage our organizations, and ourselves, to find a way out of the crisis (Kronblad \& Envall Pregmark, 2021).

Higher education systems are mostly traditionally oriented offering traditional study programmes which are performed in classical classrooms using traditional study methods and techniques. ICT and digital technologies that are involved in those traditional study methods are mostly implemented on basic levels. You will probably find one computer, projector and projector screen within the classroom for presentations and that's it. Digital skills of teachers are also on different levels, most often not at a satisfactory level. But due to COVID-19 crisis times were changed. Due to restrictions students could not attend regular classes in traditional classrooms and the whole traditional education system failed. New ICT and digital technologies are taking the main role in higher education systems. The purpose of this paper is to examine how ICT and digital technologies could help within higher education institutions. The main research question is in which fields ICT and digital technologies could help managers of higher education institutions in order to help in these challenging times to keep the teaching process going its normal course.

\section{ICT and Digital Technologies COVID-19 pandemic times}

Kimuli et al. give us a broader definition of digital technologies. It is the use of devices and Internet-based systems like computers, tablets, mobile phones, social media platforms, mobile money, closed-circuit television (CCTV) cameras, websites, smart phones, computers, printers, digital transport and digital banking in business operations. All those technologies enable companies to access markets, advertise their businesses and reach out to customers locally and internationally during and after the COVID-19 pandemic. Also they facilitate access to resources and interaction with customers and other stakeholders in the business community (Kimuli et al., 2021).

Digitalization refers to the transformation of an array of data into digital form so that they are more consistent with new tools and technologies of the digital economy and the subsequent exchange of this data through electronic communication channels. Digitalization is designed to perform routine tasks without the direct participation of the user (Ipatov et al., 2020).

The development of science, its transformation into techno-science, which reflects a symbiosis of science and technology, creates conditions for the emergence of new objects of engineering activity constituting integrated network unities, which work within new technology paradigms. 
They include the Internet of Things, Industry 4.0, TechNet, cyber-physical systems, quantum systems, smart production industry, "smart media", distributed registers, digital economy, etc (Rudskoy, 2017). Many authors are investigating how ICT and digital technologies could help in COVID-19 pandemic times (Anthony \& Noel, 2021; Bordoloi et al., 2021; Joshi, 2021; Kamysbayeva et al., 2021; Megahed \& Hassan, 2021; Milicevic et al., 2020; Pittman et al., 2021; Webb et al., 2021).

Anthony \& Noel in their study appeals on existing literature and theories of online learning and change management to provide evidence on the state of art of emergency remote teaching and virtual learning which educational institutions are deploying within learning process (Anthony \& Noel, 2021).

Bordoloi et al. examine the perceptions of both teachers and learners on the use of online learning in their regular curriculum transactions most particularly when the whole world is facing the brunt of the COVID-19 pandemic, which has adversely affected millions of learners across the world. They explored the current state of online/blended learning in a developing country like India to provide a practical and realistic vision of a new way of learning in the post-COVID-19 situations (Bordoloi et al., 2021).

Joshi examine the issues, challenges and way forward for a transition from faceto-face teaching to remote learning in the case of India. Greater use of this remote learning can be made for checking human capital deficit, preventing loss of future earnings and also for preparing a future-ready digital workforce to surf the Industry 4.0 wave (Joshi, 2021).

Kamysbayeva et al. study modern e-learning challenges in the context of social distance, the analysis of learning experience, problems and opportunities associated with online learning. Their research was carried out at the "Blinded for peer review" and involved 300 graduate students. A qualitative method based on a two-step process was used in their study and discussion allowed participants to discuss and compare personal learning experiences primarily related to the COVID-19 crisis (Kamysbayeva et al., 2021).

Megahed \& Hassan proposed a vision to reimagine post-COVID-19 education and the required blended learning strategy to provide a theoretical framework that integrates the instructional models required to be investigated by instructors (Megahed \& Hassan, 2021).

Milicevic et al. aims to point out the advantages and disadvantages of online learning, as well as its impact on student achievement, which was achieved by researching the number of applications, assessment of student turnout and taking subjects before and after isolation. The obtained results would indicate how the development of technology should be managed in the future in education systems, in order to reduce potential negative impacts to a minimum and in order to make education as high quality as possible (Milicevic et al., 2020).

Pittman et al. aims to share responses from current literature, a small case study about perceptions and practices of the school of education faculty toward multicultural and educational issues concerning the rapid rise in online environments during coronavirus (COVID-19) experiences and just-in-time strategies for addressing digital equity (Pittman et al., 2021). 
Jakovic, B.: Implementation of ICT and Digital Technologies Within Higher Educa...

Webb et. al made a review of academic and policy literature concerning digitalisation and online learning in universities and qualitative interviews with staff involved in online teaching and learning at a university in Scotland (Webb et al., 2021).

\section{Higher Education Systems}

The COVID-19 pandemic is a huge challenge to education systems. Educational institutions have quickly transitioned all academic activities online. Due to a report of UNESCO from 2020, the viral pandemic affected about 1.5 billion students. (Anthony $\&$ Noel, 2021). Pittman et al. aim that successful transition in creating culturally responsive and equitable virtual learning environments is largely dependent on teacher and teacher educators' skills and mindsets for working together collaboratively to reassess the development of new layers of culturally responsive knowledge and skills (Pittman et al., 2021). Higher education institutions have accelerated the speed at which digitalisation and digital ways of working have been embedded in organisational life and service delivery including new ways of learning and working (Webb et al., 2021).

Use of ICT and digital technology in higher education has brought some radical shifts in the learning dynamics which has mainly been facilitated by electronic learning, which involves the use of technology to enhance educational and training activities. Furthermore, the formal systems of education where students would be residents on campus undergoing formal classroom lectures has been shifting and more and more students are enrolling as part-time learners either as distance learners or block release students (Tsekea \& Chigwada, 2021).

If the world of working and living relies on collaboration, creativity, definition and framing of problems and if it requires dealing with uncertainty, change and intelligence that is distributed across minds, cultures, disciplines and tools-then education should foster competencies that prepare students for having meaningful and productive lives in such a world (Fischer et al., 2020). In order to improve faculty capacity to facilitate effective online learning, it was suggested that more professional development opportunities be enacted, that faculty be afforded more time to focus on integrating technology into their classrooms, and that IT support systems be improved to ensure teachers do not deviate from more sound, blended-learning practices (Colpitts et al., 2021).

Each practice had its own difficulties and adaptation problems during the transition to online education in universities. The transition to online education has created even more specific problems, especially in branches of science that require gathering, common working space and equipment usage (Ceylan et al., 2021)

\section{Research methods}

In researching and processing the topic of this scientific paper, the following methods were applied: analysis and synthesis, induction and deduction, description, classification, generalization, interviewing, abstraction and compilation, as well as statistical, historical and comparative methods. 
The research is based on available and relevant scientific and professional literature in the field of ICT, digital technologies and higher education. Secondary data sources such as journals, articles, books, papers and other relevant publications in printed and digital editions were used in the preparation of this paper.

\section{Usage of ICT and Digital Technologies within Higher Education Systems}

There are many different aspects how we can use ICT and digital technologies within higher education systems. First and most important is within learning process. But there are more important aspects: 1) Application of new students for study programmes 2) Communication with teachers - consultation hours 3) Communication and services with student office 4) Communication and services with other offices (International office, Career and cancelling office, Library, Souvenir Shop etc.) 5) Other activities related to student life (e.g. Online surveys, Student promotions).

ICT and digital technologies can help in the learning process through several spheres. It is crucial to hold face-to-face classes in real time where students can listen to their teachers and have interactive classes. Numerous video conferencing tools such as Zoom or Google Meet can help with this.

Another important element in the learning process is the sharing of all materials and communication between teachers and students. There are the best content sharing platform solutions like Moodle or Google Classroom.

Knowledge tests through various forms of testing are also crucial in the teaching process. Google forms, which can be used to create various quizzes and exams to test knowledge, can help a lot in this.

Another important aspect is communication between teachers and students in the form of consultations. Numerous tools can help with Google Meet, Zoom, Microsoft Teams and similar tools where consultations can take place in real time face to face as well as lectures. Some instant messaging applications such as WhatsApp or Viber can also be used for communication, and it is also possible to communicate via content sharing platforms within Moodle or Google Classroom.

In addition to the teaching process, it is crucial to digitize other jobs where the most prominent are the many activities that students do in the student office, such as enrolment in several years of study, submitting various applications, creating various certificates proving student status, selection and enrolment in elective courses, selection in the enrolment of the desired directions, etc. A good information system that will support the work of the student office and all business processes within the student office is crucial.

When applying for new study programs, it is necessary to provide an infrastructure that will enable students to enrol in the desired study program without physically coming to the student office, all online. There are also key good information systems that will allow you to download certain data from other information systems (eg. National Centre for External Evaluation of Education, lists of students that can be enrolled, etc.) upload all necessary documents by students and the signing of study contracts, GDPR statements and others required documents using a digital signature. 
Other student services must also digitize their services so that students can use their services as if they were coming to their office. The key element for communication is certainly e-mail, but there can also be very useful social networks and a good information system that will support all the services offered in these services. If there is a souvenir shop at the faculty, it is desirable that it also has a webshop so that students can hear everything from that store online.

And others actively need to adapt to the online mode. The information obtained from the students' feedback was essential for the evaluation of the academic staff and the quality of the study material delivered. Such surveys at the end of each training course are of particular importance to all academic lecturers in order to be aware to what extent he/she meets students' expectations and requirements.

In case of mismatches of views, it is possible to correct the imperfections on time. The students' opinion is particularly important about: the time usage during academic study process; the necessity for corrections or the introduction of additional topics; the logical links between practical exercises and lectures delivered (Ronkova \& Dimitrov, 2019). To conduct student surveys, it is necessary to provide a special web application that will be able to conduct online surveys without the physical presence of students, but with the provision of anonymity for students to get the best possible answers. The library should have a platform for sharing e-books and other publications that students use for required and supplementary literature.

For each higher education institution, it is necessary to provide a good infrastructure that will enable the sharing of all content with students and good communication and information. The central Website is crucial here along with profiles on the most famous social networks and other popular communication services among students.

\section{Conclusions and further research}

We can witness the great implementation of ICT and digital technology in every industry and in every organization. Without an efficient implementation of ICT and digital technologies within higher education systems, managers of higher education institutions would face huge problems ending the academic year during the COVID19 crisis. They had great challenges in the education process due to the fact that students could not come to the classrooms because of restrictions.

Modern ICT and digital technologies enabled continuous education processes in the digital environment. If managers of higher education institutions would adopt ICT and digital technologies in all aspects as it was described in this paper students could finish their academic year as they were in traditional classrooms. Negative outcomes could be in increasing investments, but positive outcomes in continuous learning processes are much higher.

Further research should focus on students' attitudes about ICT and digital technologies and their implementation within higher education systems. It should investigate different functionality of digital learning platforms and see which of them are most useful in the process of the online learning environment. 
It would be great to find out the correlation between student digital skills and their usage of digital learning platforms and their functionalities. Also it would be very interesting to find out the adoption of digital learning platforms within different countries and within different study groups.

\section{References}

Anthony Jnr, B. \& Noel, S. (2021). Examining the adoption of emergency remote teaching and virtual learning during and after COVID-19 pandemic, International Journal of Educational Management, Vol. ahead-of-print, No. ahead-of-print., https://doi.org/10.1108/IJEM-08-2020-0370

Bordoloi, R., Das, P. \& Das, K. (2021). Perception towards online/blended learning at the time of COVID-19 pandemic: an academic analytics in the Indian context, Asian Association of Open Universities Journal, Vol. 16, No. 1, pp. 4160, https://doi.org/10.1108/AAOUJ-09-2020-0079

Ceylan, S., Şahin, P., Seçmen, S., Somer, M.E. \& Süher, K.H. (2021). An evaluation of online architectural design studios during COVID-19 outbreak, Archnet-IJAR, Vol. 15, No. 1, pp. 203-218, https://doi.org/10.1108/ARCH-10-2020-0230

Colpitts, B.D.F., Smith, M.D. \& McCurrach, D.P. (2021). Enhancing the digital capacity of EFL programs in the age of COVID-19: the ecological perspective in Japanese higher education, Interactive Technology and Smart Education, Vol. 18, No. 2, pp. 158-174, https://doi.org/10.1108/ITSE-08-2020-0123

Fischer, G., Lundin, J. \& Lindberg, J.O. (2020). Rethinking and reinventing learning, education and collaboration in the digital age-from creating technologies to transforming cultures, International Journal of Information and Learning Technology, Vol. 37, No. 5, pp. 241-252, https://doi.org/10.1108/JJILT-04-2020-0051

Ipatov, O., Barinova, D, Odinokaya, M., Rubtsova, A, \& Pyatnitsky, A. (2020). The Impact of Digital Transformation Process of the Russian University, Proceedings of the 31st DAAAM International Symposium, pp.0271-0275, B. Katalinic (Ed.), Published by DAAAM International, ISBN 978-3-902734-29-7, ISSN 1726-9679, Vienna, Austria, DOI: 10.2507/31st.daaam.proceedings.037

Joshi, S. (2021). Rising importance of remote learning in India in the wake of COVID19: issues, challenges and way forward, World Journal of Science, Technology and Sustainable Development, Vol. 18, No. 1, pp. 44-63, https://doi.org/10.1108/WJSTSD10-2020-0079

Kamysbayeva, A., Koryakov, A., Garnova, N., Glushkov, S. \& Klimenkova, S. (2021). E-learning challenge studying the COVID-19 pandemic, International Journal of Educational Management, Vol. ahead-of-print, No. ahead-ofprint, https://doi.org/10.1108/IJEM-06-2021-0257

Kimuli, S.N.L., Sendawula, K. \& Nagujja, S. (2021). Digital technologies in micro and small enterprise: evidence from Uganda's informal sector during the COVID-19 pandemic, World Journal of Science, Technology and Sustainable Development, Vol. 18, No. 2, pp. 93-108, https://doi.org/10.1108/WJSTSD-02-2021-0017

Kronblad, C. \& Envall Pregmark, J. (2021). Responding to the COVID-19 crisis: the rapid turn toward digital business models, Journal of Science and Technology Policy 
Management, Vol. ahead-of-print, No. ahead-of-print, https://doi.org/10.1108/JSTPM10-2020-0155

Megahed, N. \& Hassan, A. (2021). A blended learning strategy: reimagining the postCOVID-19 architectural education, Archnet-IJAR, Vol. ahead-of-print, No. ahead-ofprint, https://doi.org/10.1108/ARCH-04-2021-0081

Milicevic, J., Sremcev, N., Cosic, I., Ralevic, N. \& Lazarevic, M. (2020). Online Learning Pros and Cons During Covid Pandemic: A Case Results Students in a Higher Education Institution, Chapter 12 in DAAAM International Scientific Book 2020, pp.151-170, B. Katalinic (Ed.), Published by DAAAM International, ISBN 978-3902734-27-3, ISSN 1726-9687, Vienna, Austria, DOI: 10.2507/daaam.scibook. 2020.12

Pittman, J., Severino, L., DeCarlo-Tecce, M.J. \& Kiosoglous, C. (2021). An action research case study: digital equity and educational inclusion during an emergent COVID-19 divide, Journal for Multicultural Education, Vol. 15, No. 1, pp. 68-84, https://doi.org/10.1108/JME-09-2020-0099

Ronkova, V. \& Dimitrov, Y. (2019). Education in Engineering - Challenges and Contributions, Proceedings of the 30th DAAAM International Symposium, pp.07170723, B. Katalinic (Ed.), Published by DAAAM International, ISBN 978-3-90273422-8, ISSN 1726-9679, Vienna, Austria, DOI: 10.2507/30th.daaam.proceedings.098 Rudskoy, A., Ipatov, O. \& Sergeev, S. (2017). Paradigms of Polytechnic Education in the Evolving Technogenic World, DAAAM International Scientific Book 2017, pp.145-154, B. Katalinic (Ed.), Published by DAAAM International, ISBN 978-3902734-12-9, ISSN: 1726-9687, Vienna, Austria, DOI: 10.2507/daaam.scibook. 2017.12

Tsekea, S. \& Chigwada, J.P. (2021). COVID-19: strategies for positioning the university library in support of e-learning, Digital Library Perspectives, Vol. 37, No. 1, pp. 54-64, https://doi.org/10.1108/DLP-06-2020-0058

Webb, A., McQuaid, R.W. \& Webster, C.W.R. (2021). Moving learning online and the COVID-19 pandemic: a university response, World Journal of Science, Technology and Sustainable Development, Vol. 18, No. 1, pp. 119, https://doi.org/10.1108/WJSTSD-11-2020-0090 